\title{
Pelatihan Penggunaan Aplikasi Tes Fisik Untuk Pelatih Sekolah Sepakbola Di Bawah Binaan KONI Ogan Ilir
}

\author{
Hartati $^{1}$, Ahmad Richard Victoriand ${ }^{2}$, Herri Yusfi ${ }^{3}$, Destriani ${ }^{4}$ \\ Penjaskes FKIP Universitas Sriwijaya
}

Hartati@fkip.unsri.ac.id,Richarda2@gmail.com,herriyusfi@ fkip.unsri.ac.idDestriani@fkip

.unsri.ac.id

\begin{abstract}
Abstrak
Pelatihan Tes Dan Pengukuran fisik atlet yang menggunakan aplikasi pada permainan sepakbola bertujuan untuk mensosialisasikan aplikasi tes fisik cabang olahraga sepakbola kepada pelatih sekolah sepakbola di bawah binaan KONI Kabupaten Ogan Ilir. Metode yang digunakan dalam pelatihan ini yaitu dengan menampilkan aplikasi tes fisik yang telah dibuat suatu program latihan sesuai dengan hasil penelitian. Yang dilaksanakan kepada pelatih SSB di bawah binaan KONI Ogan Ilir, jumlah peserta 50 orang, yang terdiri pelatih SSB dan guru olahraga yang terlibat dalam latihan sepakbola di Ogan Ilir. Hasil pelatihan ini pelatih dapat menggunakan aplikasi tes fisik sepakbola, dan mempermudah atlet dalam pelaksanaan tes fisik cabor sepakbola. Manfaat pengabdian ini ingin meningkatkan kualitas pelatih sepakbola/ SSB di Kabupaten Ogan Ilir di masa yang akan datang.
\end{abstract}

Kata Kunci : Pelatihan, Aplikasi Tes Fisik, Pelatih, Sepakbola

\section{Abstract}

Physical Test and Measurement Training athletes who use the application on soccer games aim to socialize the physical tes application for the soccer branch to the coaches of soccer schools under the guidance of the OI Ilir District KONI. The method used in this training is by displaying a physical tes application that has been made an exercise program in accordance with the results of the study. What was done to the SSB coach was under the guidance of KONI Ogan Ilir, the number of participants was 50 people, consisting of SSB trainers and sports teachers involved in soccer practice in Ogan Ilir. The results of this training the trainer can use the physical soccer tes application, and make it easier for athletes to carry out physical tess of soccer sports. The benefit of this service is to improve the quality of the soccer coach / SSB in Ogan Ilir District in the future.

Keywords: Training, Physical Tes Application, Trainers, Football 


\section{PENDAHULUAN}

Tes dan pengukuran merupakan bagian yang tak terpisahkan dalam berbagai kegiatan manusia, demikian pula halnya dalam kegiatan pengajaran dan pelatihan olahraga. Karena dengan melaksanakan kedua hal tersebut dapat mengetahui kelebihan dan kekurangan seorang atlet, sehingga akhirnya dapat membuat suatu keputusan yang tepat (Mylsidayu \& Kurniawan, 2015).

Perkembangan ilmu pengetahuan dan teknologi dalam olahraga sudah mengalami kemajuan, baik dalam ilmu kepelatihan atau dalam tes pengukuran fisik di era globalisasi ini, hasil dari sebuah tes hendaknya menggunakan sebuah aplikasi komputer atau sofware yang bisa mencatat dan menghitung seluruh tes yang diikuti atlet dan mengetahui tingkat kesegaran fisik atlet atau VO2max setiap atlet. Modul dasar pemrograman visual basic merupakan bahasa yang sangat mudah dipelajari, dengan teknik pemrograman visual yang memungkinkan penggunanya untuk berkreasi lebih baik dalam dalam menghasilkan suatu program aplikasi. Ledakan pemakaian Visual Basic ditandai dengan kemampuan Visual Basic untuk berinteraksi dengan aplikasi lain didalam sistem operasi Windows dengan komponen Active Control. Dengan komponen ini memungkinkan pengguna untuk memanggil dan menggunakan semua model data yang ada didalam system operasi windows. Visual Basic 6.0 masih merupakan pilihan pertama di dalam membuat program aplikasi yang ada di pasar perangkat lunak nasional. Hal ini disebabkan oleh kemudahan dalam melakukan proses development dari aplikasi yang dibuat.

Masalah selama ini pada tes fisik atlet, data hasil tes fisik dihitung dengan cara manual, menghitung dengan manual masih lambat dan rumus-rumus terbatas, dengan mengembangkan perhitungan dari manual dan excell menggunakan perhitungan visual basic yang bertujuan mempercepat perhitungan dan mempertepat hasil perhitungan. Dengan dihasilkannya produk baru berupa alikasi tes fisik untuk atlet sepakbola maka perlu adanya sosialisasi agar pelatih-pelatih tes fisik dapat menggunakan aplikasi tersebut, sehingga produk yang dihasilkan dapat bermanfaat bagi pelatih-pelatih fisik sepakbola. Pelatih-pelatih sepakbola mengalami permasalahan pada tes fisik atlet sepakbola sehingga dengan adanya apliksi tes fisik yang telah dibuat maka perlu adanya sosialisasi dan pelatihan dalam penggunaan aplikasi tes fisik tersebut. Dengan demikian dapat dirumuskan permasalahan bagi pelatihpelatih fisik cabang olahraga sepakbola di bawah binaan KONI Kabupaten Ogan Ilir yaitu bagaimana sosialisasi penggunaan aplikasi tes fisik cabor olahraga sepakbola pada pelatihan sekolah sepakbola (SSB) di bawah pembinaan KONI Ogan Ilir, dan Bagaimana meningkatkan pemahaman pelatih SSB dalam menggunakan aplikasi tesfisik cabang olahraga sepakbola?

\section{METODE}

Kegiatan pengabdian pada masyarakat yang akan dilakukan ini secara teknis melibatkan kerjasama antara unit penelitian dan pengabdian pada masyarakat (UPPM) Universitas Sriwijaya, Program Studi Pendidikan Jasmani dan Kesehatan, dengan pelatih SSB dibawah binaan Komite Olahraga Nasional Indonesia (KONI) Kabupaten Ogan Ilir. Dengan metode pelatihan menggunakan model pendampingan. Narasumber memberikan pelatihan kepada peserta dengan metode ceramah, kemudian setelah dilakukan penjelasan, peserta melakukan praktik langsung dengan pendampingan yang dilakukan oleh beberapa narasumber pelatihan. Peserta pelatihan yaitu pelatih SSB di bawah binaan KONI Ogan Ilir, dengan jumlah peserta 50 orang, yang terdiri pelatih SSB dan guru olahraga yang 
terlibat dalam latihan sepakbola di Ogan Ilir.

\section{HASIL DAN PEMBAHASAN HASIL}

Evaluasi adalah suatu rencana penilaian terhadap aspek pelatihan seperti evaluasi proses dan evaluasi hasil. Evaluasi proses meliputi pencapaian tujuan pelatihan yang dilakukan dengan angket tanya jawab dan observasi, sedangkan evaluasi aspek penyelenggaraan pelatihan meliputi pemberian angket untuk melihat indikator keberhasilan dalam pelaksanaan pelatihan penggunaan aplikasi melalui evaluasi selama proses pelatihan, dan evaluasi pasca pelatihan.

Evaluasi saat pelaksanaan pelatihan meliputi, keterlibatan dan kemampuan peserta setiap tahap pelatihan. Pada tahap akhir peserta diharapkan dapat melakukan kegiatan tehnis penulisan artikel ilmiah olahraga, yaitu: 1) mengidentifikasi, memilih dan merumuskan fungsi aplikasi; 2) membandingkan tes dengan aplikasi dan tes secara manual; 3) mengevaluasi tes fisik yang ada di aplikasi 4)mempraktekan penggunaan aplikasi tes fisik., sedangkan indikator keberhasilan selama proses pelatihan dengan memperhatikan beberapa hal seperti kemampuan pelatih dalam pemahaman kegiatan penggunaan aplikasi tes fisik yaitu: 1) mengidentifikasi, memilih dan merumuskan fungsi aplikasi; 2) membandingkan tes dengan aplikasi dan tes secara manual; 3) mengevaluasi tes fisik yang ada di aplikasi 4) mempraktekan penggunaan aplikasi tes fisik.

Keterampilan pelatih dalam pemahaman kegiatan penggunaan aplikasi tes fisik yaitu: 1) mengidentifikasi, memilih dan merumuskan fungsi aplikasi; 2) membandingkan tes dengan aplikasi dan tes secara manual; 3) mengevaluasi tes fisik yang ada di aplikasi, 4) mempraktekan penggunaan aplikasi tes fisikJumlah pelatih yang mampu dengan baik dan secara terampil melakukan kegiatan tehnis. Indikator keberhasilan pelatihan ini adalah apabila: 1) lebih dari 90\% peserta/pelatih memahami kegiatan pelaksanaan pelatihan penggunaan aplikasi tes fisik; 2) lebih dari $75 \%$ mampu mempraktekkan yaitu penggunaan aplikasi tes fisik; 3) lebih dari 50\% pelatih bersedia mensosialisasikan penggunaan aplikasi tes fisik.

Berdasarkan indikator keberhasilan diperoleh evaluasi yaitu kemampuan pelatih SSB sudah memahami tentang penggunaan aplikasi tes fisik. Pelatih terampil dalam menggunakan aplikasi walaupun menemukan kendala. $85 \%$ pelatih mampu mempraktekan menggunakan aplikasi tes fisik dan $80 \%$ pelatih bersedia mensosialisasikan tentang aplikasi tes fisik cabang sepakbola kepada rekan sejawat.

\section{PEMBAHASAN}

Pelatih sekolah sepakbola di Kabupaten Ogan Ilir mempunyai kemauan dan kemampuan untuk dilatih penggunaan aplikasi. Pelatih antusias dan termotivasi untuk menggunakan aplikasi. Hal ini dilihat pada saat sesi tanya jawab, pelatih bertanya tentang materi penggunaan. Pada saat praktek pelatih sudah mengetahui dan dapat menerapkannya mulai mengidentifikasi kesulitan-kesulitan sampai dengan kesimpulan. Dilihat dari profesi dan pengalamannya, pelatih SSB memiliki potensi, pengetahuan dan kemampuan untuk menggunakan aplikasi tes fisik.

Berdasarkan potensi masing-masing pihak terkait dalam kegiatan pelatihan ini, bentuk pendampingan dan kerjasama menghadirkan sinergisme yang amat strategis dan positif antara lembaga perguruan tinggi dengan yang akan mendapatkan pelatihan dari tenaga edukatif terlatih profesional perguruan tinggi untuk meningkatkan kompetensinya dalam penggunaan aplikasi tes fisik dan wahana strategis untuk menyebarluaskan 
ilmu pengetahuan pendidikan dengan sasaran dan jangkauan yang lebih luas yaitu pelatih SSB di kabupaten ogan ilir.

Dosen dan mahasiswa tim pengabdian pada masyarakat berperan strategis dalam setiap kegiatan baik pada kegiatan penyuluhan atau penataran maupun pada kegiatan pelatihan. Masingmasing anggota tim menjalankan tugas dan fungsi yang relevan dengan materi- materi pelatihan dan dosen senantiasa selalu berdampingan dalam memberikan bantuan cara penggunaan aplikasi. Dalam kegiatan pelatihan penggunaan aplikasi masingmasing anggota bertindak sebagai penceramah, pembimbing, dan pendamping atau pengarah dalam bantuan teknis penggunaan aplikasi.

\section{SIMPULAN}

Berdasarkan hasil dan pembahasan disimpulkan bahwa kegiatan pelatihan penggunaan aplikasi tes fisik atlet cabang olahraga sepakbola sangat cocok diterapkan. Pelatih mampu menggunakan aplikasi dan pealtih bersedia mensosialisasikan tentang aplikasi tes fisik kepada rekan sejawat. Hal ini dapat mengembangkan profesi pelatih dengan baik yang dapat membantu untuk kenaikan pangkat.

Berdasarkan simpulan di atas, disarankan beberapa hal berikut ini, kegiatan pelatihan penggunaan aplikasi bagi pelatih SSB dilanjutkan ditahun berikutnya yaitu:

1. Kegiatan pelatihan penggunaan aplikasi bagi pelatih SSB melibatkan lebih banyak pelatih dalam setiap metode.

2. Dosen Pendidikan Jasmani dan kesehatan lebih banyak membantu pelatih dalam kegiatan pelatihan.

\section{DAFTAR PUSTAKA}

Mylsidayu, A., \& Kurniawan, F. (2015). Ilmu Kepelatihan Dasar. Bandung: CV Alfabeta.

Moeleok, D. (1998). Kesehatan Dan Olahraga. Jakarta: Fakultas Kedokteran UI.

Irianto, D. P. (2002). Dasar Kepelatihan. Yogyakarta: Fakultas Ilmu Keolahragaan Universitas Negeri Yogyakarta.

Febrianti, R. (2016). Tes Dan Pengukuran. Surakarta: Universitas Surakarta

Sajoto. (1985). Pembinaan Kondisi Fisik Dalam Olahraga. Jakarta: Depdikbud

UU Nomor 20 Tahun 2003 Tentang Sistem Pendidikan Nasional. Jakarta: Pustaka Pelajar 